\title{
IN VITRO STUDIES ON THE SYNERGISTIC EFFECT OF MORINDA CITRIFOLIA L. (NONI) AND METHOTREXATE ON CYTOTOXICITY OF HELA CELL LINES
}

\author{
MHATRE BHAKTI, MARAR THANKAMANI* \\ School of Biotechnology and Bioinformatics, D.Y. Patil Deemed to be University, Sector 15, CBD Belapur, Navi Mumbai - 400 614, \\ Maharashtra, India. Email: dr.marar@yahoo.com
}

Received: 09 January 2019, Revised and Accepted: 01 March 2019

\section{ABSTRACT}

Objective: Cancer remains to be one of the leading causes of death around the world. Modern targeted therapies have undeniably improved cancer patients' survival, but search still continues for safer and more effective drugs. This work is an attempt to assess the effectiveness of cotreatment of aqueous fruit extract of Morinda citrifolia L. (Noni) on methotrexate (MTX)-induced cytotoxicity on HeLa cancer cell line.

Methods: HeLa cells were treated with different concentrations of MTX and Noni alone and in combination for 24 and 48 h and studied for the cytotoxic effects by various approaches.

Results: There was a dose-dependent inhibition of growth when treated with MTX in a dose range of $0.045-45.4 \mu \mathrm{g} / \mathrm{ml}$ and Noni for a dose range of 0.3-30 mg/ml for $48 \mathrm{~h}$. The $\mathrm{IC}_{50}$ for MTX was $4.45 \mu \mathrm{g} / \mathrm{ml}(1 \mu \mathrm{M} / \mathrm{ml})$, and for Noni, it was $8 \mathrm{mg} / \mathrm{ml}$ while the combination exhibited a more intensive growth inhibitory effect. Our results were confirmed with phase-contrast microscopy, whereby the number of viable cells decreased with an increase in the concentration of Noni. Cells were found to have rounded up and detached from the flask indicating apoptosis. Apoptosis in HeLa cell lines was further confirmed by DNA fragmentation and flow cytometry.

Conclusion: It can be concluded that Noni may enhance MTX cytotoxicity by inducing apoptosis and cell cycle arrest. Hence, cotreatment with Noni may reduce the dosage of MTX necessary for inhibiting proliferation of malignant cells and hence decrease the toxic effects of MTX on the system.

Keywords: Morinda citrifolia L., Methotrexate, HeLa cell lines, DNA fragmentation, Flow cytometry, Apoptosis.

(C) 2019 The Authors. Published by Innovare Academic Sciences Pvt Ltd. This is an open access article under the CC BY license (http://creativecommons. org/licenses/by/4. 0/) DOI: http://dx.doi.org/10.22159/ajpcr.2019.v12i4.31290

\section{INTRODUCTION}

Many nutraceuticals and plant active compounds are an important historical and ethnobotanical source for developing drugs with broad-spectrum pharmacological activities such as anticancer, antitumor, and antioxidant. An increasing incidence of cancer in developing and developed countries has promoted research toward dietary and medicinal plant extracts as supplements and prophylactics essentially due to the presence of phenolic acids, flavonoids, and phenolic diterpenes [1]. Chemotherapy and radiation on human cells continuously lead to the generation of reactive oxygen radicals, causing noxious effects due to potentially heavy loads of oxidants. Usage of alternative medicine is a necessity of the hour as they can be protective and can possess antioxidant and antitumor agents which can be more effective and reduce toxicity due to the presence of phytochemicals $[2,3]$. In the present study, we have used methotrexate (MTX) which is an antineoplastic drug widely used in the treatment of several diseases such as autoimmune diseases, lymphoma, and lymphoblastic leukemia but has been associated with mild-to-severe liver and intestinal toxicity. Aqueous fruit extract from Morinda citrifolia L. (Noni), which has a diverse array of active phytoconstituents with multitude of pharmacological activities, has been used for cotreatment in our study. Noni is used as an herbal remedy and has promising antioxidant properties [4].

Currently, there is a growing interest to understand and analyze the herb-drug interactions. Most of the oncologists do not recommend herbal medicines since it can interact with chemotherapeutic drug decreasing the therapeutic benefits. Rather, antioxidants are compounds which can act as radical scavengers if present in food products and avoid radical chain reaction, delay oxidation, and increase the life of cells by retarding lipid peroxidation [5]. Attractive approaches to prevent toxicity of different organs should involve the use of natural antioxidants. In this study, we introduce a combination of Noni with MTX to study anticancer effects against cervical cancer cell line, HeLa.

\section{METHODS}

HeLa cell lines P89 were obtained from the National Center for Cell Science, Pune. Fetal bovine serum was purchased from Pan Biotech, and Penicillin-Streptomycin antibiotic solution, sodium pyruvate solution, Dulbecco's Modified Eagle Medium (DMEM), and Dulbecco's phosphatebuffered saline (PBS $\times 10$ ) were obtained from Mu Lifesciences, Mumbai, India.

Folitrax $15 \mathrm{mg} / \mathrm{ml}$ of MTX injection was used, and MTX stock was filter sterilized and used in different concentrations ranging from $0.045 \mu \mathrm{g}$ / $\mathrm{ml}$ to $45.4 \mu \mathrm{g} / \mathrm{ml}$ for the assays.

Noni extract was diluted in DMEM and filter sterilized. Concentrations ranging from $0.3 \mathrm{mg} / \mathrm{ml}$ to $30 \mathrm{mg} / \mathrm{ml}$ were used for the assays.

\section{MTT-based cytotoxicity assay}

Cytotoxicity assay was performed as described by Mosmann (1983) [6]. Cells were trypsinized and 2500 cells $/ 200 \mu \mathrm{l}$ were seeded per well of 96well plate. Experiments were prepared in triplicates, and the cells were incubated at $37^{\circ} \mathrm{C}$ in $\mathrm{CO}_{2}$ incubator. After $16 \mathrm{~h}$, the medium from the well was replaced with medium containing different concentrations of $M$. citrifolia $L$. fruit extract $(0.3-30 \mathrm{mg} / \mathrm{ml})$. Separate wells were treated with varying concentration of MTX $(0.045-45.4 \mu \mathrm{g} / \mathrm{ml})$ and with IC $_{50}$ of MTX in combination with varying concentrations of $M$. citrifolia $L$. fruit extract. Control and negative control were also maintained. After $48 \mathrm{~h}$ of incubation with drug, $20 \mu \mathrm{l}$ of MTT stock solution was added per well and incubated for $4 \mathrm{~h}$ at $37^{\circ}$ for formazan crystal formation. 
The supernatant was carefully discarded taking care of not losing the formazan crystals. The crystals were dissolved by adding $100 \mu \mathrm{l}$ of DMSO, and absorbance was read on a Bio Rad microplate reader (version 680) at $570 \mathrm{~nm}$ with a reference wavelength of $655 \mathrm{~nm}$. The experiment was repeated 3 independent times in triplicates and percentage of inhibition was calculated.

\section{Phase-contrast microscopy}

Approximately $1 \times 10^{4}$ cells were seeded in a 24 multi-well plate for phase-contrast microscopy. After $24 \mathrm{~h}$, the medium was discarded and cells were supplemented with fresh medium. Cells were treated with MTX at a final concentration of $0.045-45.4 \mu \mathrm{g} / \mathrm{ml}$ alone, $0.3-30 \mathrm{mg} / \mathrm{ml}$ of M. citrifolia L. fruit extract, and in combination along with $\mathrm{IC}_{50}(4.54 \mu \mathrm{g} / \mathrm{ml})$ of MTX with varying concentrations of M. citrifolia $L$. fruit extract for $48 \mathrm{~h}$. A separate well of control was also maintained. Phase-contrast microscopy study of treated and non-treated cells was performed using Inverted Microscope Nikon ECLIPSE TS100.

\section{DNA laddering assay}

DNA was extracted by the method of Gong et al. (1994) [7].

HeLa cells $\left(2 \times 10^{5}\right)$ were seeded for DNA laddering assay in culture plates. After $24 \mathrm{~h}$, the medium was discarded and cells were washed with $\times 1$ PBS $(\mathrm{pH}$ 7.4) and fresh DMEM medium was added. Cells were treated with final concentration $\mathrm{IC}_{50}(4.54 \mu \mathrm{g} / \mathrm{ml})$ of MTX of alone, $\mathrm{IC}_{50}(8 \mathrm{mg} / \mathrm{ml})$ of Noni alone, and in combination with $\mathrm{IC}_{50}$ of Noni and MTX. A separate control was also maintained. After $48 \mathrm{~h}$ incubation, the supernatant was collected and adhered cells were harvested by trypsin treatment.

Electrophoresis was carried out at $60 \mathrm{~V}$ until the loading dye migrated about three-fourth of the gel. DNA molecular marker of 500-1000 bp was run alongside the samples. The DNA was visualized by observing the gel using gel documentation system (Syngene).

\section{Clonogenic assay}

Clonogenic assay was performed as per the method of Buch et al. (2012) [8].

Clonogenic assay was performed on exponentially growing cells. A total of 500 cells were seeded in 6 multi-well plates in $1 \mathrm{ml}$ of complete DMEM medium and allowed to adhere overnight. After $16 \mathrm{~h}$, the medium was removed and replaced with medium containing $\mathrm{IC}_{50}(4.54 \mu \mathrm{g} / \mathrm{ml})$ of MTX alone, $\mathrm{IC}_{50}(8 \mathrm{mg} / \mathrm{ml})$ of Noni alone, and in combination with $\mathrm{IC}_{50}$ of Noni and MTX. A separate control was also maintained. After $48 \mathrm{~h}$, cells were fed with fresh DMEM medium. After 9 days of treatment, media were carefully removed and then washed with PBS. Cells were then fixed with methanol: acetic acid (3:1) and stained using $0.5 \%$ crystal violet in methanol for $15 \mathrm{~min}$. Cells were washed again with PBS and colonies were observed. Treated and non-treated cells were photographed and each experiment was repeated in triplicate.

\section{Flow cytometry-based apoptosis detection}

Flow cytometry analysis of apoptotic cells was done as per the method of Riccardi and Nicoletti (2006), Balakrishnan and Bhat (2014), and Da'i et al. (2017) [9-11]. Approximately $1 \times 10^{5}$ cells were seeded in multiple 6-well plate for flow cytometry and apoptosis detection. After $16 \mathrm{~h}$, the medium was discarded and cells were supplemented with fresh medium containing $\mathrm{IC}_{50}(4.54 \mu \mathrm{g} / \mathrm{ml})$ of MTX alone, $\mathrm{IC}_{50}(8 \mathrm{mg} / \mathrm{ml})$ of Noni alone, and in combination with IC $_{50}$ of Noni and MTX. A separate control was also maintained. After $24 \mathrm{~h}$ of treatment, the supernatant was collected and adhered cells were harvested by trypsin treatment in a tube for each concentration-treated cells. The tubes were centrifuged at $2500 \mathrm{rpm}$ for $10 \mathrm{~min}$ to obtain a cell pellet. The supernatant was discarded and cell pellet was washed with $1 \mathrm{ml}$ of PBS (pH 7.4).

The cells were then fixed by adding pre-chilled $2 \mathrm{ml}$ of $70 \%$ ethanol dropwise to the pellet. The cells at this stage were stored for a week at $-4^{\circ} \mathrm{C}$ and then processed for analysis. During analysis, cells were first centrifuged at $2500 \mathrm{rpm}$ for $10 \mathrm{~min}$. Ethanol was discarded and cells were washed with PBS (pH 7.4) to remove ethanol completely. $500 \mu \mathrm{l}$ of PBS was again added to the cell pellet, and the cells were passed gently through 26-gauge needle 3-4 times. $50 \mu \mathrm{l}$ of RNase A and $5 \mu \mathrm{l}$ of Triton X-100 were then added to the microfuge tube and incubated at $37^{\circ} \mathrm{C}$ for $30 \mathrm{~min} .12 .5 \mu \mathrm{l}$ of propidium iodide was added per tube at a concentration of $1 \mathrm{mg} / \mathrm{ml}$ and incubated in the dark at $37^{\circ} \mathrm{C}$ for 20 min. The DNA content of the cells was analyzed on BD Accuri Flow Cytometer. C6 analysis software program was used for acquisition and percentage of cells undergoing apoptosis.

\section{Statistical analysis of data}

Data are presented as mean \pm standard deviation. The statistical significance was assessed using one-way analysis of variance followed by Student's t-test. In figures and tables, symbols represent statistical significance as indicated: ${ }^{*} \mathrm{p}<0.05,{ }^{* *} \mathrm{p}<0.01,{ }^{* * *} \mathrm{p}<0.001$ and NS: Nonsignificant.

\section{RESULTS}

\section{Cytotoxicity of Noni and MTX}

Cytotoxic effect of MTX and Noni alone and in combination on HeLa cell lines was checked first with an exposure time of $24 \mathrm{~h}$, but, since it did not show any significant effect on the HeLa cells, then it was increased to $48 \mathrm{~h}$.

Fig. 1 shows enhanced cytotoxic effect with increasing concentration of MTX from $0.045 \mu \mathrm{g} / \mathrm{ml}$ to $45.4 \mu \mathrm{g} / \mathrm{ml}$ for $48 \mathrm{~h}$. A low dose of MTX $(0.0454 \mu \mathrm{g} / \mathrm{ml})$ showed inhibition of cell growth at around $10 \%, \mathrm{IC}_{50}$

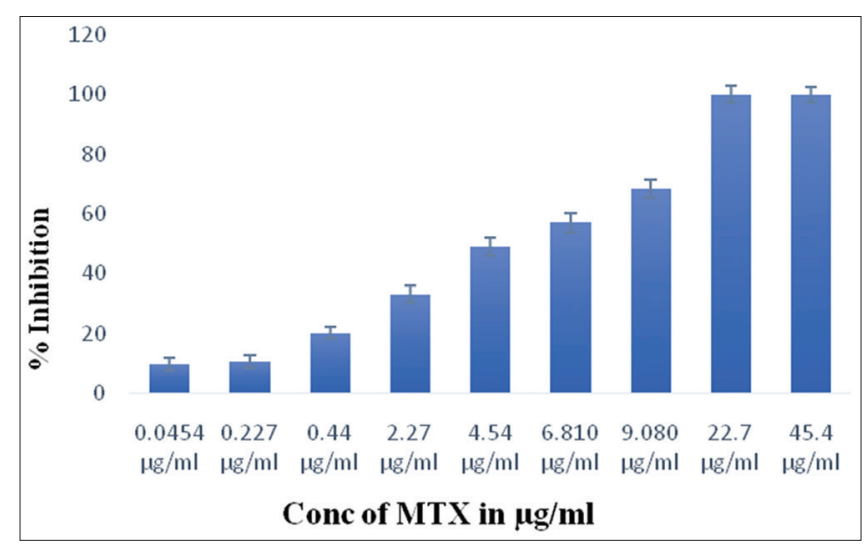

Fig. 1: Cell viability of HeLa cells with different concentrations of methotrexate by MTT assay. Data represent cell viability with different concentrations of MTX after $48 \mathrm{~h}$ with mean \pm standard deviation value from three independent determinations in triplicates

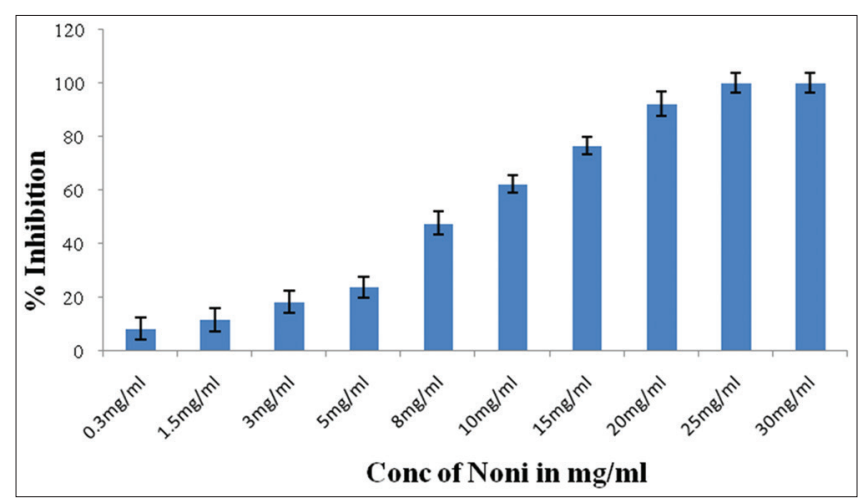

Fig. 2: Cell viability on HeLa cells with different concentrations of Noni by MTT assay. Data represent cell viability with different concentrations of Noni after $48 \mathrm{~h}$ with mean \pm standard deviation value from three independent determinations in triplicates 


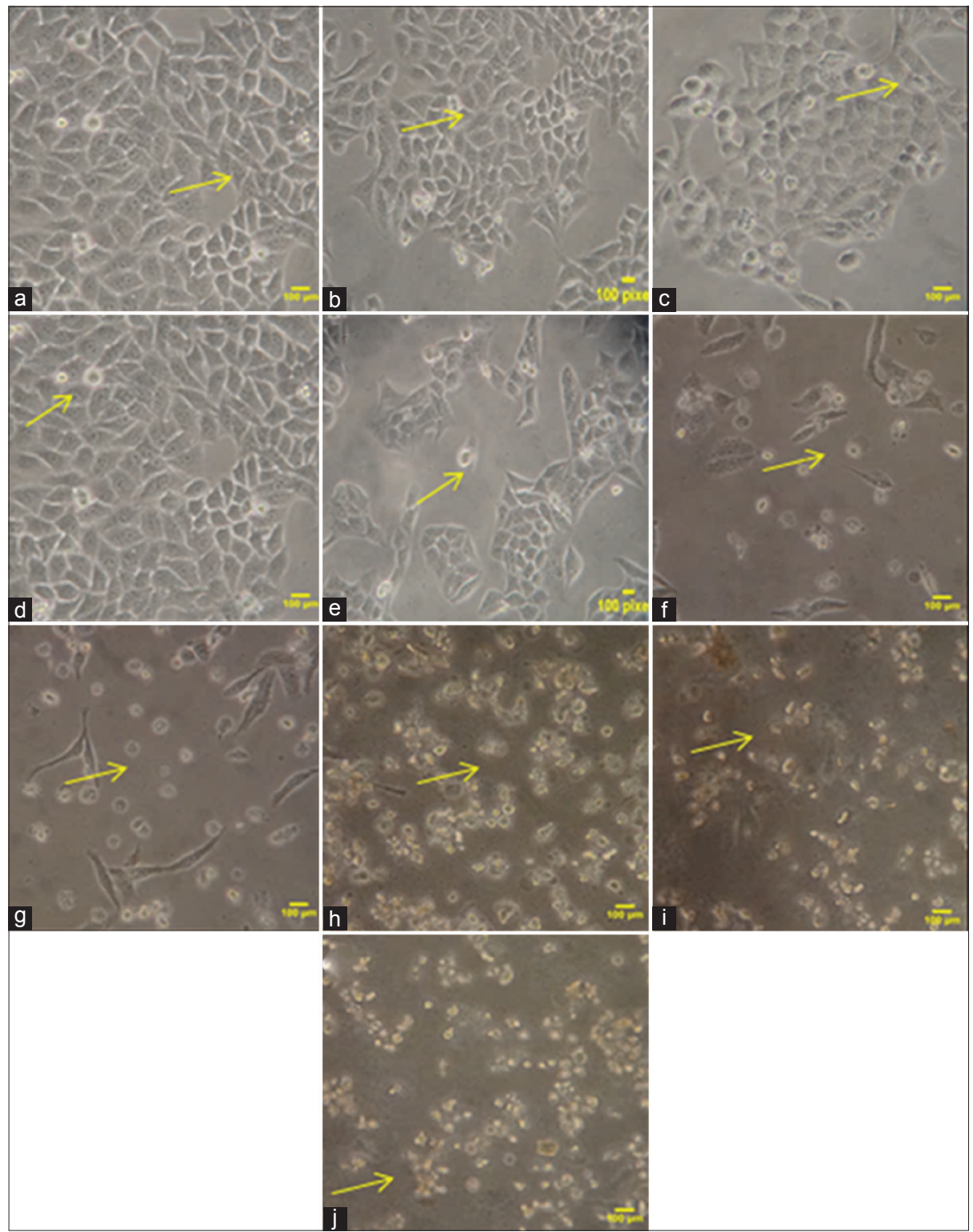

Plate 1: Representative photomicrographs of methotrexate (MTX)-treated HeLa cell's morphology. Cells exposed to increasing concentrations of MTX. (a) None. (b) $0.0454 \mu \mathrm{g} / \mathrm{ml}$. (c) $0.227 \mu \mathrm{g} / \mathrm{ml}$. (d) $0.44 \mu \mathrm{g} / \mathrm{ml}$. (e) $2.27 \mu \mathrm{g} / \mathrm{ml}$. (f) $4.54 \mu \mathrm{g} / \mathrm{ml}$. (g) $6.810 \mu \mathrm{g} / \mathrm{ml}$. (h) $9.080 \mu \mathrm{g} / \mathrm{ml}$. (i) $22.7 \mu \mathrm{g} / \mathrm{ml}$. (j) $45.4 \mu \mathrm{g} / \mathrm{ml}$

value was found to be at of $4.45 \mu \mathrm{g} / \mathrm{ml}(1 \mu \mathrm{M} / \mathrm{ml})$, and $100 \%$ cytotoxicity of MTX was observed at $22.7 \mu \mathrm{g} / \mathrm{ml}$ for $48 \mathrm{~h}$.

Fig. 2 shows the cell viability results of Noni in a dose range of $0.3-30 \mathrm{mg} / \mathrm{ml}$, used for standardization. $\mathrm{IC}_{50}$ value for Noni was found to be $8 \mathrm{mg} / \mathrm{ml}$.

Fig. 3 shows the results of the combination of Noni in varying concentrations with MTX IC ${ }_{50}$ value of $4.45 \mu \mathrm{g} / \mathrm{ml}$. Noni was found to inhibit the viability of cells with an increase in concentration along with $\mathrm{IC}_{50}$ value of MTX.

Study of the morphology of HeLa cells after MTX and Noni treatment

Morphological alterations in HeLa cell lines treated with MTX alone, Noni alone, and combination of Noni and MTX along with control were observed under an inverted microscope. Control plates with 75-80\% confluency appeared to be healthy. Considerable cytotoxicity was observed in HeLa cells treated with varying concentration of MTX in range of $0.0454-45.4 \mu \mathrm{g} / \mathrm{ml}$ for $48 \mathrm{~h}$. Distinctive apoptotic features such as cellular shrinkage, reduction in cell volume, cytoplasmic

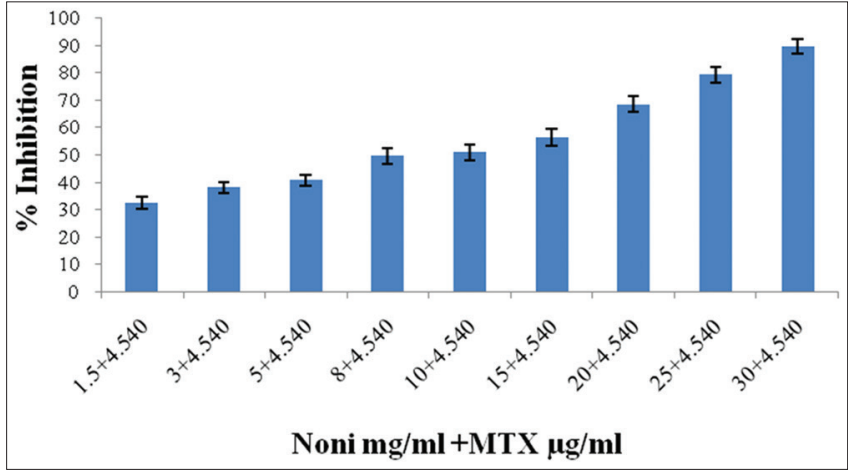

Fig. 3: Cell viability of HeLa cells with different concentrations of Noni and IC $\mathrm{IC}_{50}$ value of methotrexate (MTX) in combination with MTT assay. Data represent cell viability with different concentrations of Noni in the presence of IC $_{50}$ value of MTX after $48 \mathrm{~h}$ with mean \pm standard deviation value from three independent determinations in triplicates 


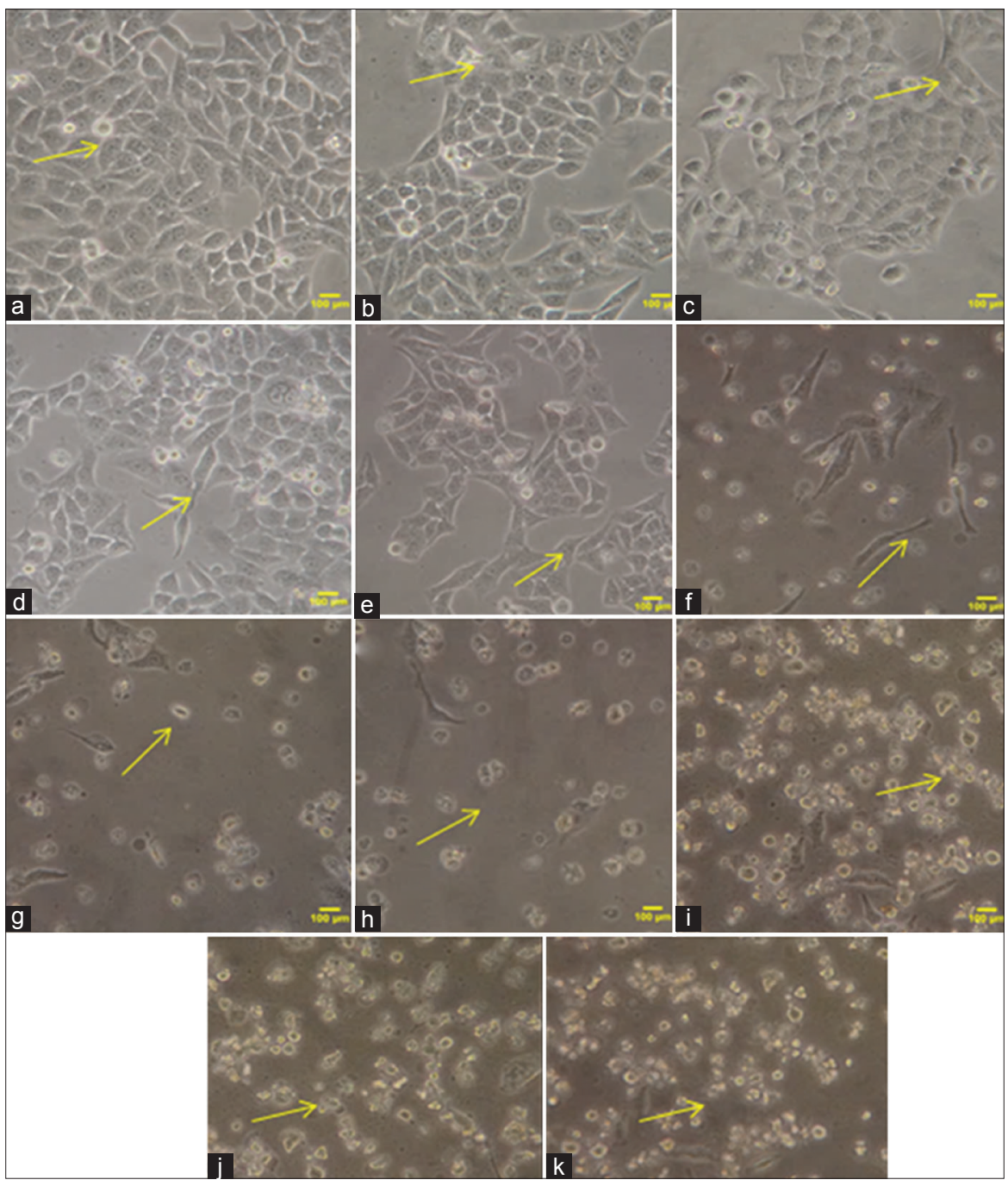

Plate 2: Representative photomicrographs of Morinda citrifolia L. fruit extract-treated HeLa cells, morphology. Cells exposed to increasing concentrations of $M$. citrifolia L. fruit extract. (a) None. (b) $0.3 \mathrm{mg} / \mathrm{ml}$. (c) $1.5 \mathrm{mg} / \mathrm{ml}$. (d) $3 \mathrm{mg} / \mathrm{ml}$. (e) $5 \mathrm{mg} / \mathrm{ml}$. (f) $8 \mathrm{mg} / \mathrm{ml}$. (g) $10 \mathrm{mg} / \mathrm{ml}$. (h) $15 \mathrm{mg} / \mathrm{ml}$. (i) $20 \mathrm{mg} / \mathrm{ml}$. (j) $25 \mathrm{mg} / \mathrm{ml}$. (k) $30 \mathrm{mg} / \mathrm{ml}$

constriction and membrane blebbing was also observed (Plate 1e-h). With an increase in the concentration of MTX (Plate 1h-k), the number of attached viable cells decreased and maximum cells were found to be floating.

HeLa cells treated with varying concentrations of Noni from $0.3 \mathrm{mg} / \mathrm{ml}$ to $30 \mathrm{mg} / \mathrm{ml}$ also showed concentration-dependent cytotoxicity (Plate 2).

Plate 3 shows HeLa cells treated with a combination of MTX $\mathrm{IC}_{50}(4.45 \mu \mathrm{g} / \mathrm{ml})$, and varying concentrations of Noni also show cellular shrinkage and reduction in volume (Plate 3 - e, f and g); similarly, floating cells are observed in Plate 3g-j also.

Plate 4 shows morphology of HeLa cells treated with control (a), $8 \mathrm{mg} / \mathrm{ml}$ of Noni (b), $4.54 \mu \mathrm{g} / \mathrm{ml}$ MTX treated cells (c), and $8 \mathrm{mg} / \mathrm{ml}$ Noni $+4.54 \mu \mathrm{g} / \mathrm{ml}$ MTX treated cells (d) showing reduction in cell number as compared to that of control.

\section{Effect of MTX and Noni on HeLa cell clonogenic assay}

Clonogenic assay measures the ability of the cell to retain its normal morphological characteristics, proliferation, and the effectiveness of a cytotoxic agent is added to cancer cells [12]. With increase in concentration of cytotoxic agent there is loss of reproductive integrity and inability to proliferate leading to cell death [13].

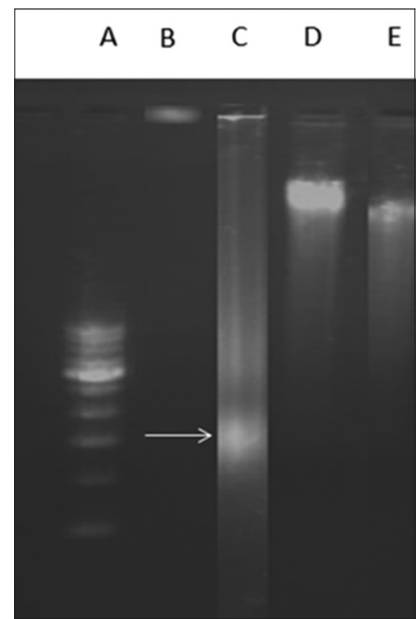

Fig. 4: Effect of Noni on methotrexate (MTX)-induced DNA fragmentation. Alphabets indicate wells loaded with DNA isolated from cells after different treatments stained with (a) DNA Ladder 500-1000 bp, (b) untreated cells, (c) $4.54 \mu \mathrm{g} / \mathrm{ml}$ MTX treated, (d) Noni $8 \mathrm{mg} / \mathrm{ml}+$ MTX $4.54 \mu \mathrm{g} / \mathrm{ml}$ treated, (e) Noni $8 \mathrm{mg} / \mathrm{ml}$ treated. Arrow indicates characteristic ladder pattern observed in apoptotic cells seen in lane $C$ 


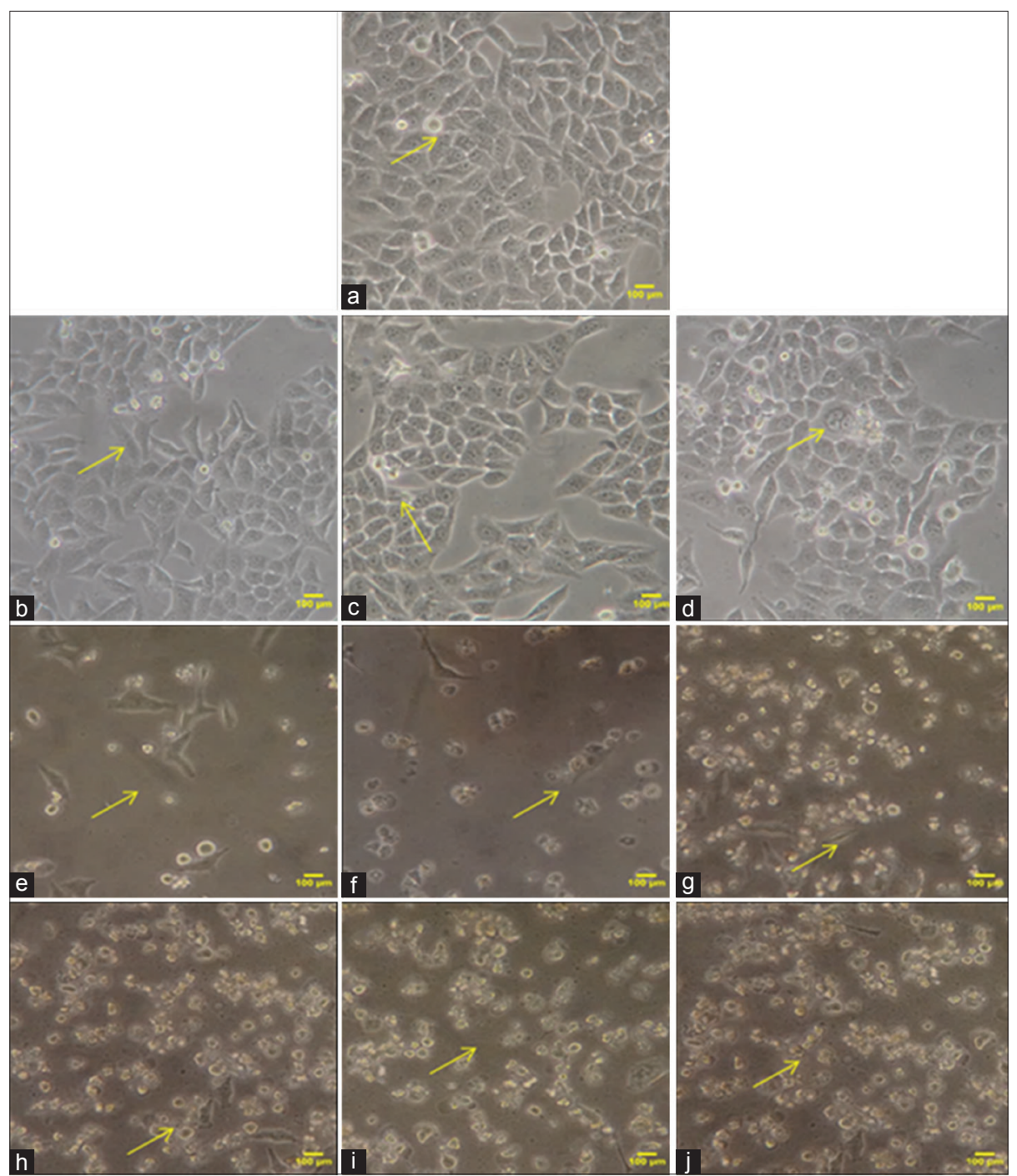

Plate 3: Representative photomicrographs of HeLa cells treated with combination of methotrexate (MTX) and Noni. Cells exposed to combination of varying concentrations of Noni and $4.540 \mu \mathrm{g} / \mathrm{ml}$ of MTX. (a) None. (b) $1.5 \mathrm{mg} / \mathrm{ml} \mathrm{of} \mathrm{Noni.} \mathrm{(c)} 3 \mathrm{mg} / \mathrm{ml} \mathrm{of} \mathrm{Noni.} \mathrm{(d)} 5 \mathrm{mg} / \mathrm{ml}$ of Noni. (e) $8 \mathrm{mg} / \mathrm{ml}$ of Noni. (f) $10 \mathrm{mg} / \mathrm{ml}$ of Noni. (g) $15 \mathrm{mg} / \mathrm{ml}$ of Noni. (h) $20 \mathrm{mg} / \mathrm{ml} \mathrm{of} \mathrm{Noni.} \mathrm{(i)} 25 \mathrm{mg} / \mathrm{ml} \mathrm{of} \mathrm{Noni.} \mathrm{(j)} 30 \mathrm{mg} / \mathrm{ml} \mathrm{of} \mathrm{Noni}$

Colony formation ability of HeLa cells when treated with MTX and Noni fruit extract was assessed. Our study shows that HeLa cells are sensitive to MTX alone, Noni alone, and combination of Noni and MTX in comparison to control (Plate 5). Since cells number was less than 50, plating efficiency could not be calculated.

As can be observed in Plate 5, cells treated with MTX IC $_{50}$ value $(4.54 \mu \mathrm{g} / \mathrm{ml})$, Noni IC $_{50}$ value $(8 \mathrm{mg} / \mathrm{ml})$, and a combination of $8 \mathrm{mg} / \mathrm{ml} \mathrm{Noni}$ and $4.54 \mu \mathrm{g} / \mathrm{ml}$ MTX showed distinct fragments that ultimately lead to collapse of the cells, nuclear disintegration, destabilization of nuclear envelope, and lamin proteolysis (Plate 4 - b, c, d). These photographs establish the synergistic effect of Noni fruit juice on MTX-induced cytotoxicity.

\section{Effect of Noni and MTX on DNA fragmentation}

Apoptosis is a distinctive feature of cell death due to the release of nuclear DNA from apoptotic cells. HeLa cell lines treated with MTX and Noni were analysed for DNA fragmentation. DNA ladder 500-100bp was used for comparison. (Fig. 4a) DNA of cells treated with MTX IC ${ }_{50}$ (Fig. 4c) showed ladder with some smearing. There was no DNA fragmentation or smearing of DNA in control (Fig. 4b), but the combination of Noni + MTX and Noni alone showed smearing which might be due to necrosis of cells (Fig. $4 \mathrm{~d}$ and e). This also serves as a vital biochemical marker for measurement of drug-mediated cytotoxicity.

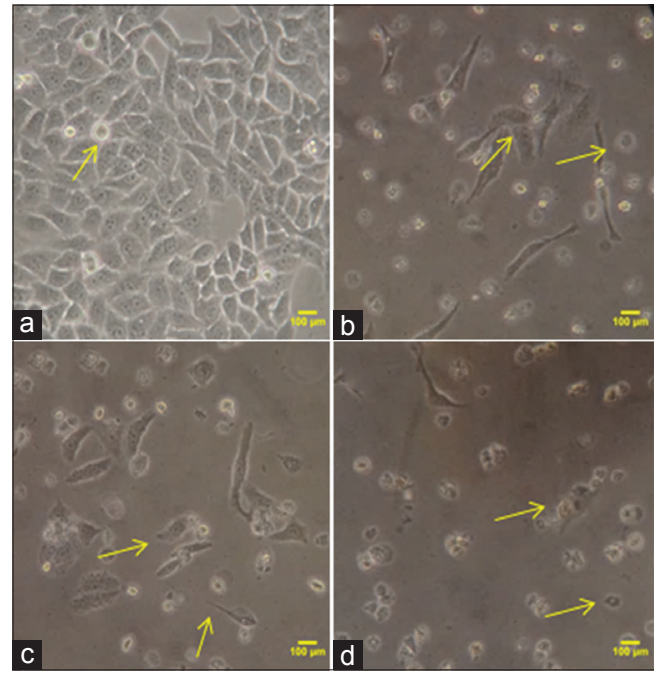

Plate 4: Representative photomicrograph showing morphology of HeLa cells. Cells treated with (a) none. (b) $8 \mathrm{mg} / \mathrm{ml}$ of Noni.

(c) $4.54 \mu \mathrm{g} / \mathrm{ml}$ methotrexate (MTX). (d) $8 \mathrm{mg} / \mathrm{ml} \mathrm{Noni} \mathrm{+}$ $4.54 \mu \mathrm{g} / \mathrm{ml}$ MTX-treated cells 


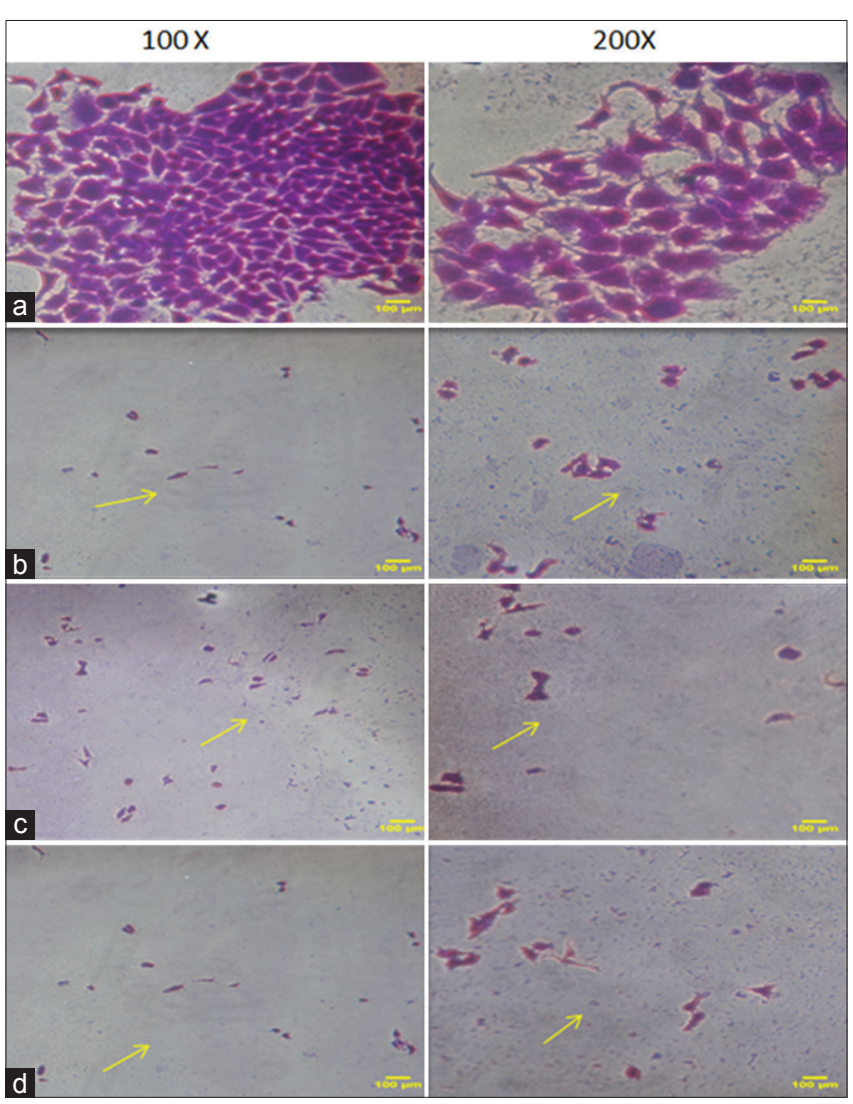

Plate 5: Photomicrograph showing morphology of methotrexate (MTX)-treated HeLa cells post-clonogenic assay stained with $0.5 \%$ crystal violet in methanol $(\times 100$ and $\times 200)$. (a) Growing colony of untreated HeLa cells. (b) $8 \mathrm{mg} / \mathrm{ml}$ Noni pre-treated cells with abnormal morphology. (c) $4.54 \mu \mathrm{g} / \mathrm{ml}$ MTX pre-treated cells with abnormal morphology. (d) $8 \mathrm{mg} / \mathrm{ml}$ Noni $+4.54 \mu \mathrm{g} / \mathrm{ml}$ MTX pre-treated cells with narrower, long strips, stretched out tentacle-like structures, observed under $\times 100$ and $\times 200$

Flow cytometry to study the effect of Noni on MTX-induced apoptosis on cell lines

Cells experience a mode of cellular suicide called apoptosis under normal physiological conditions. Cell undergoing apoptosis shows morphological characteristic changes such as formation of round apoptotic bodies appearing like round spherical beads, nuclear condensation, and shrinkage [14].

Flow cytometry and propidium iodide staining was used to investigate antiproliferative effect of Noni and chemotherapeutic drug MTX on the cell cycle distribution of HeLa cells.

Control cell showed a $6.3 \% \pm 2.56$ of apoptotic cells and $93.7 \%$ displayed characteristic normal cell cycle distribution. All the analyses were done in triplicates.

Fig. $5 \mathrm{a}$ and $\mathrm{b}$ shows a number of cells captured with no gate and gate $\mathrm{R}^{2}$ later. Fig. $5 \mathrm{c}$ and $\mathrm{d}$ represents the subgenomic cells in sub G1 phase peak in red color which determines the number of apoptotic cells in the control. Black peak indicates G0-G1 phase.

Cells treated with Noni $\mathrm{IC}_{50} 8 \mathrm{mg} / \mathrm{ml}$, however, showed $9.4 \% \pm 3.38$ of apoptotic cells and $90.60 \%$ viable cells.

Fig. $6 \mathrm{a}$ and $\mathrm{b}$ shows a number of cells captured with no gate and gate $\mathrm{R}^{2}$ later. Fig. $6 \mathrm{c}$ and d represents the sub G1 phases which determine the number of apoptotic cells in the Noni $\mathrm{IC}_{50} 8 \mathrm{mg} / \mathrm{ml}$.
Cells treated with MTX IC $4.54 \mu \mathrm{g} / \mathrm{ml}$, however, showed $25.86 \% \pm 7.78$ of apoptotic cells and $74.14 \%$ viable cells. Fig. $7 \mathrm{a}$ and $\mathrm{b}$ shows a number of cells captured with no gate and gate $\mathrm{R}^{2}$ later. Fig. $7 \mathrm{c}$ and $\mathrm{d}$ represents the sub G1 phases which determine the number of apoptotic cells in the $\mathrm{IC}_{50} 4.54 \mu \mathrm{g} / \mathrm{ml}$.

Cells treated with Noni and MTX, however, showed $21.13 \% \pm 2.68$ of apoptotic cells and $78.87 \%$ viable cells. Fig. $8 \mathrm{a}$ and b shows a number of cells captured with no gate and gate $\mathrm{R}^{2}$ later. Fig. $8 \mathrm{c}$ and $\mathrm{d}$ represents the sub G1 phases which determine the number of apoptotic cells in the Noni and MTX.

Our results indicate that cytotoxicity of Noni or MTX by themselves and in combination as detected by MTT assay and clonogenic assay showed a decrease in survival of cancer cells. As shown in Fig. 9a, combination of Noni and MTX can enhance apoptosis as compared to either Noni alone $(p<0.001)$ or MTX alone $(p<0.001)$. Fig. $9 b$ is a pictorial representation of multiple samples run in gated ( $\mathrm{P} 5$ in $\mathrm{R}^{2}$ ). Black peak represents control with $89.41 \%$ viable cells and $10 \%$ apoptotic cells. Red peak represents Noni extract-treated cells with $75.20 \%$ viable cells and $24.8 \%$ apoptotic cells. Blue peak represents cells treated with Noni +MTX showing $71.83 \%$ viable cells and $28.17 \%$ apoptotic cells; similarly, green peak represents cells treated with MTX showing $61.36 \%$ viable cells and $38.64 \%$ apoptotic cells.

Even though the number of apoptotic cells appears to be more in pictorial graph (Fig. 9b), Fig. 9a shows a greater number of apoptotic cells in Noni and MTX in comparison to that of MTX alone in histogram. This could be due to the scatter of cells obtained during acquisition of data.

\section{DISCUSSION}

Natural plant compounds have attracted attention as alternative therapeutics in the fight against diseases, primarily due to their low toxicity and high therapeutic index. Plant-derived drugs such as vinblastine, vincristine, taxol, and camptothecin are already accepted as potent chemotherapeutic agents. Here, we explore the antiproliferative potential of fruit extracts of M. citrifolia alone and in combination with a well-accepted drug, MTX, by in vitro methods.

Our results for viability assay performed on MTX alone, Noni alone, and combination of Noni with MTX-treated cells were found to be highly significant. Singh et al. (2013) have also reported that addition of varying concentration of Noni alone, cisplatin alone, and combination of both reduced the cell survivals, respectively, by $22 \%, 29 \%$, and $50 \%$ in HeLa cell lines [15]. The concentration of cisplatin used in their study was $10 \mu \mathrm{g} / \mathrm{ml}$ and Noni extract used was $10 \%, \mathrm{v} / \mathrm{v}$ for $24 \mathrm{~h}$.

In our study, we have observed that about $50 \%$ of HeLa cells showed cytotoxicity even with a concentration of $8 \mathrm{mg} / \mathrm{ml}$ of Noni alone and MTX $4.54 \mu \mathrm{g} / \mathrm{ml}$ alone, whereas a minimum dose of MTX $4.54 \mu \mathrm{g} / \mathrm{ml}$ in combination with Noni $(8 \mathrm{mg} / \mathrm{ml})$ is sufficient enough to be $52 \%$ cytotoxic after $48 \mathrm{~h}$, showing an additive effect and hence proving that small amount of chemotherapeutic drug can be used along with Noni as a chemoadjuvent to boost the cytotoxic potential.

Noni by itself has a cytotoxic effect on HeLa cell lines. Cells rounded up and detached from the plate and their neighbouring cells with subsequent condensation of cytoplasm. Dissolution of nuclear envelope along with separation of the nucleus into distinct fragments leading to collapse of cells into several small intact vesicles were also observed. A similar result was seen when we combined the $\mathrm{IC}_{50}$ value of MTX with increasing concentration of Noni. Plasma membrane blebbing, collapse of cells, number of viable cells decreased with an increase in concentration, and retraction were observed in treatment with $\mathrm{IC}_{50}$ value of MTX and increasing concentration of Noni.

Our studies indicate that Noni co-treatment with lower dose of MTX can induce morphological changes such as, necrosis and cell death 

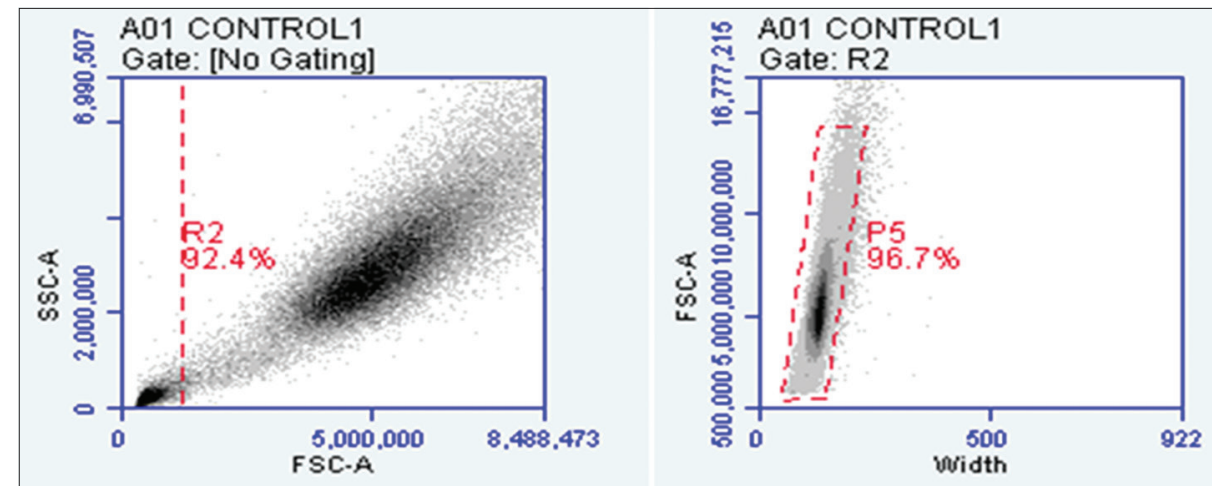

a

b
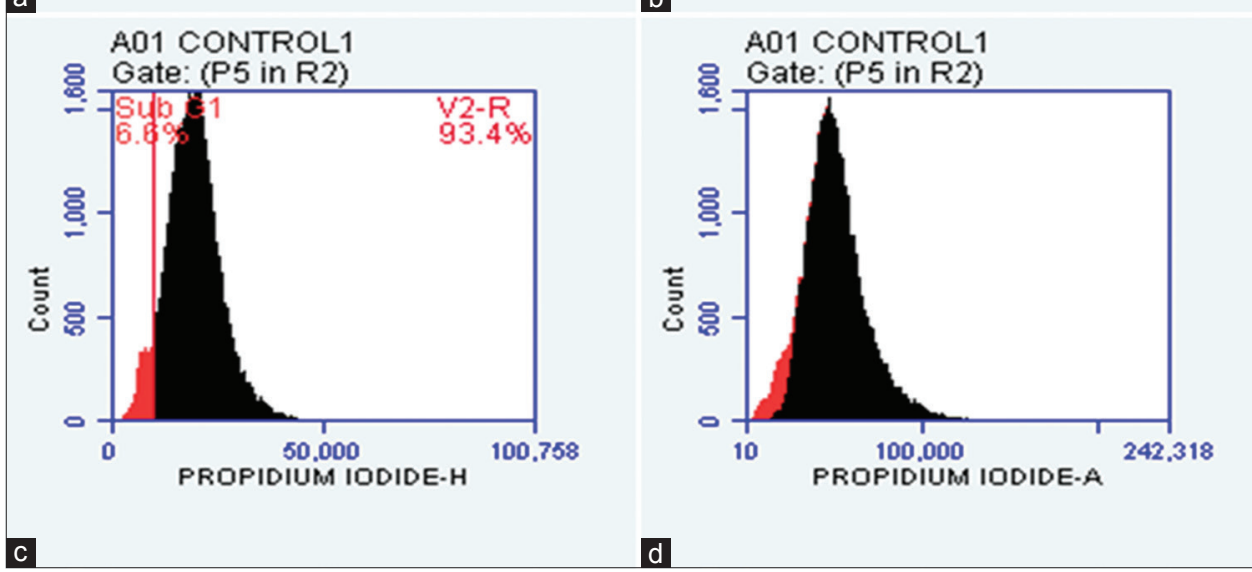

Fig. 5: (a-d) Representative histogram showing quantitative detection of apoptotic population in control HeLa cells by flow cytometry
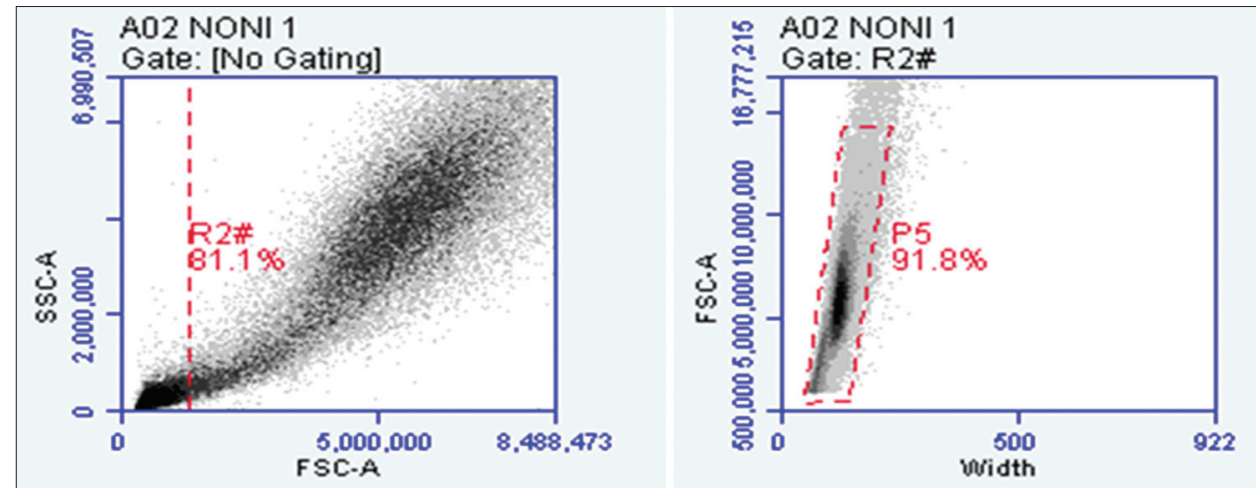

a

b
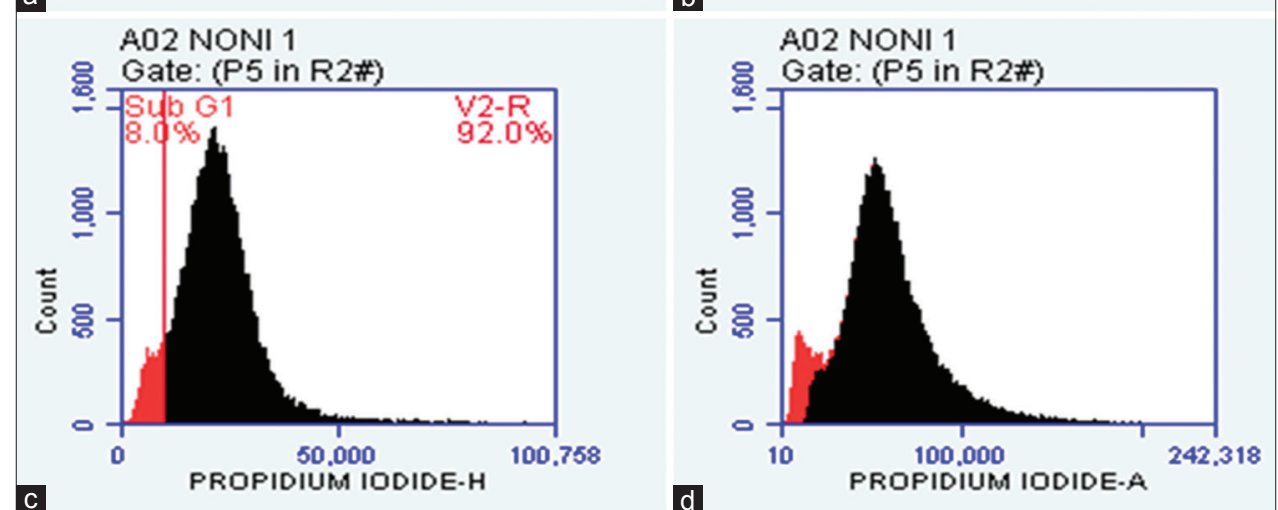

Fig. 6: (a-d) A representative histogram showing quantitative detection of apoptotic population in $8 \mathrm{mg} / \mathrm{ml}$ of Noni-treated HeLa cells by flow cytometry 


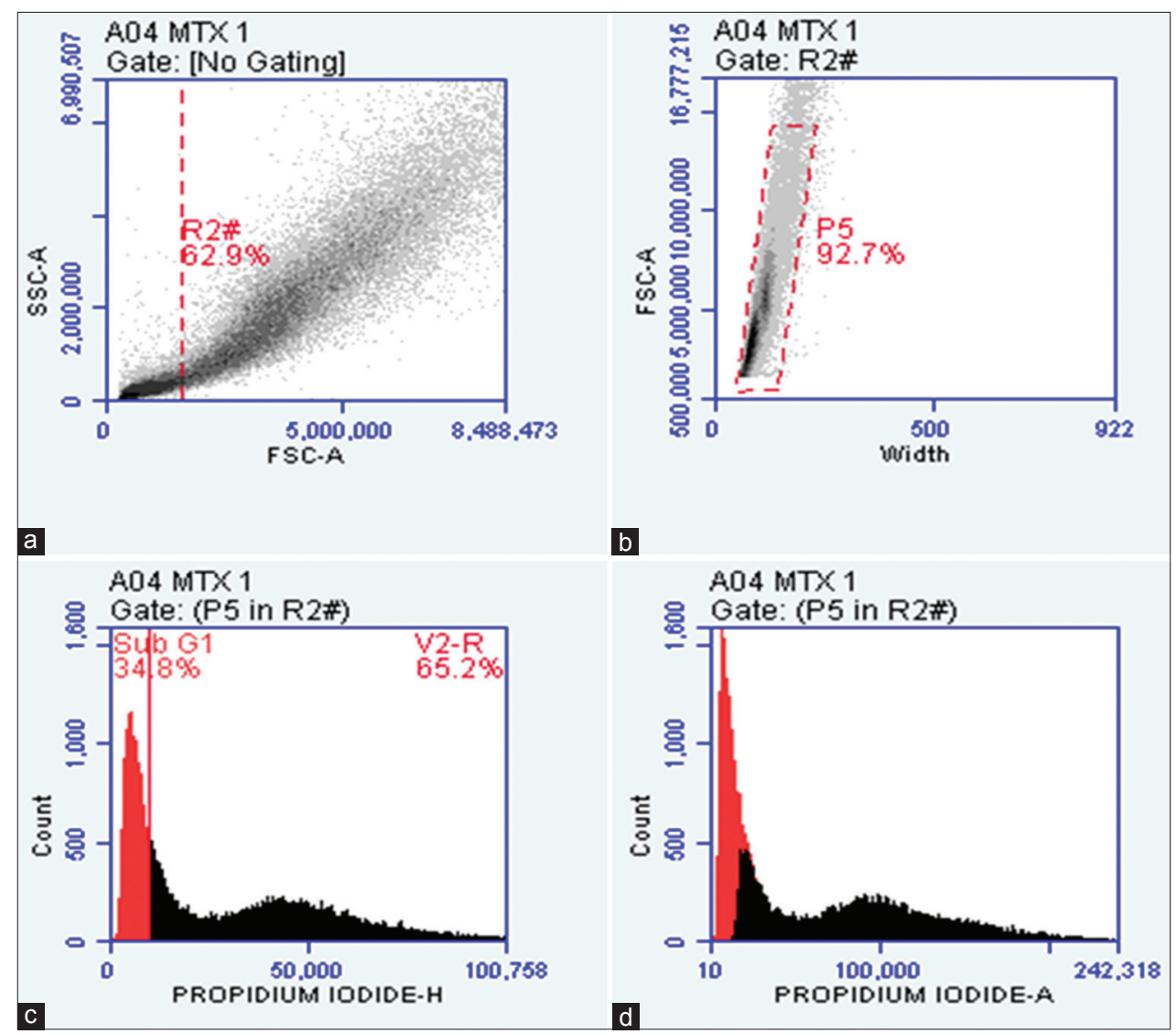

Fig. 7: (a-d) A representative histogram showing quantitative detection of apoptotic population in $4.54 \mu \mathrm{g} / \mathrm{ml}$ of methotrexate-treated HeLa cells by flow cytometry

proving to be very good cytotoxic agent, equivalent to higher doses of MTX alone.

Similar cytotoxicty with extracted chlorophyllin from fresh leaves of M. citrifolia L. has been also reported on Hep G2 and Vero cell lines [16], which suggest higher safety ratio, indicating potential use in cancer treatment as the extract inhibits only the growth of cancer cells but not normal cells.

Clonogenic assay is a conventional and more frequently used in vitro assay to visually witness cloning efficiency. Chemotherapeutic drug leads to remarkable phenotypic changes, [17] and damage to chromosomes leading to apoptosis [18]. This assay detects the ability of all cells that have retained the capacity for producing a large number of progenies after treatment.

The studies on the effect of curcumin-induced apoptosis in human mammary carcinoma cells (MDA-MB-23) reported by Latifah et al. (2006) are similar to our results, which again emphasize Noni fruit juice's synergistic effect on cytotoxicity induced by MTX [19].

Consistent slow growth rate, inability to form clones, no surviving colonies, and only few cells were observed in all the three plates that were treated with Noni and MTX. We observed that the cell number in MTX alone, Noni alone, and combination of Noni and MTX was less than 50 as compared to that of control.

Induction of apoptosis in HeLa cell lines was confirmed by DNA fragmentation. These degraded DNA produces a ladder pattern which is a hallmark of cytotoxicity and drug-induced apoptosis in cancer cells as observed on an agarose gel [20]. Xie et al. (2016) have stated that MTX can be lethal to cancer cells, as well as normal cells, and hence, the use of a combination of Noni and MTX can be more beneficial in the treatment of cancer [21]. Breakdown of cellular DNA caused due to activation of endogenous nuclear endonucleases and proteases, cleave double-stranded DNA at sites situated on linker DNA leading to DNA laddering. The release of these enzymes from cytoplasmic membrane is a sign of inhibition of DNA replication.

Treated or damaged cells can be evaluated by cell cycle analysis. Certain checkpoints are interrupted due to damage that occurs in the cell during cell cycle, hence preventing normal cells from being transformed into cancer cells [9].

G1 phase nuclei of apoptotic cells contain less DNA than healthy cells. Apoptosis is evaluated by quantification of percentage cells in the sub-G1 phase. A sub G0/G1 peak was seen before G1 in a flow cytometry histogram. Cycle cell analysis carried out to check the synergistic effect of Noni and MTX on HeLa cell lines showed an increment in sub G0/G1 population indicating the occurrence of apoptosis which was in concurrence to decrement in the percentage of viable cells in MTT and clonogenic assays.

Sharma et al. (2016) reported that cell cycle distribution in MCF -7 and MDA-MB-231 cell when exposed to Noni ethyl acetate extract at IC $\mathrm{C}_{50}$ for 24,48 , and $72 \mathrm{~h}$ showed a noticeable increase in the G1/S phase in a time-dependent manner [20]. They have reported $81 \%$ apoptotic cells which are comparable to our results for the same time duration [22]. Our results are also in accordance with Gupta et al. (2013) and Alitheen et al. $(2016)[2,23]$. The latter have used the combination of doxorubicin and damnacanthal, and the population of MCF-7 cells decreased more when treated in a combination of two rather than individual agents alone.

Combination therapy (Noni and MTX) remarkably increased apoptotic index, thereby promising herbal-based anticancer agent. An important homeostatic mechanism can be established by induction of apoptosis 


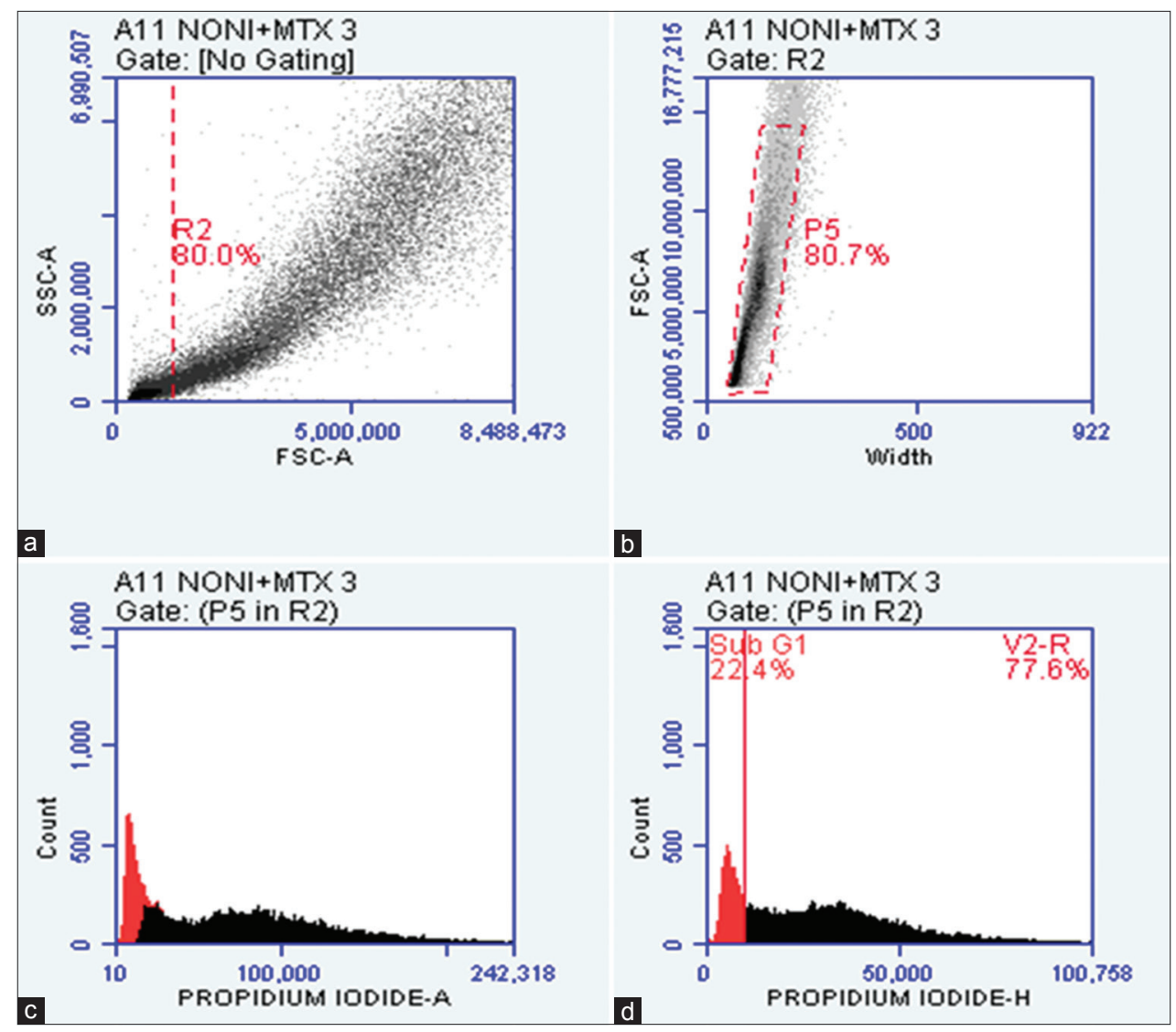

Fig. 8: (a-d) A representative histogram showing quantitative detection of apoptotic population in Noni + methotrexate-treated HeLa cells by flow cytometry

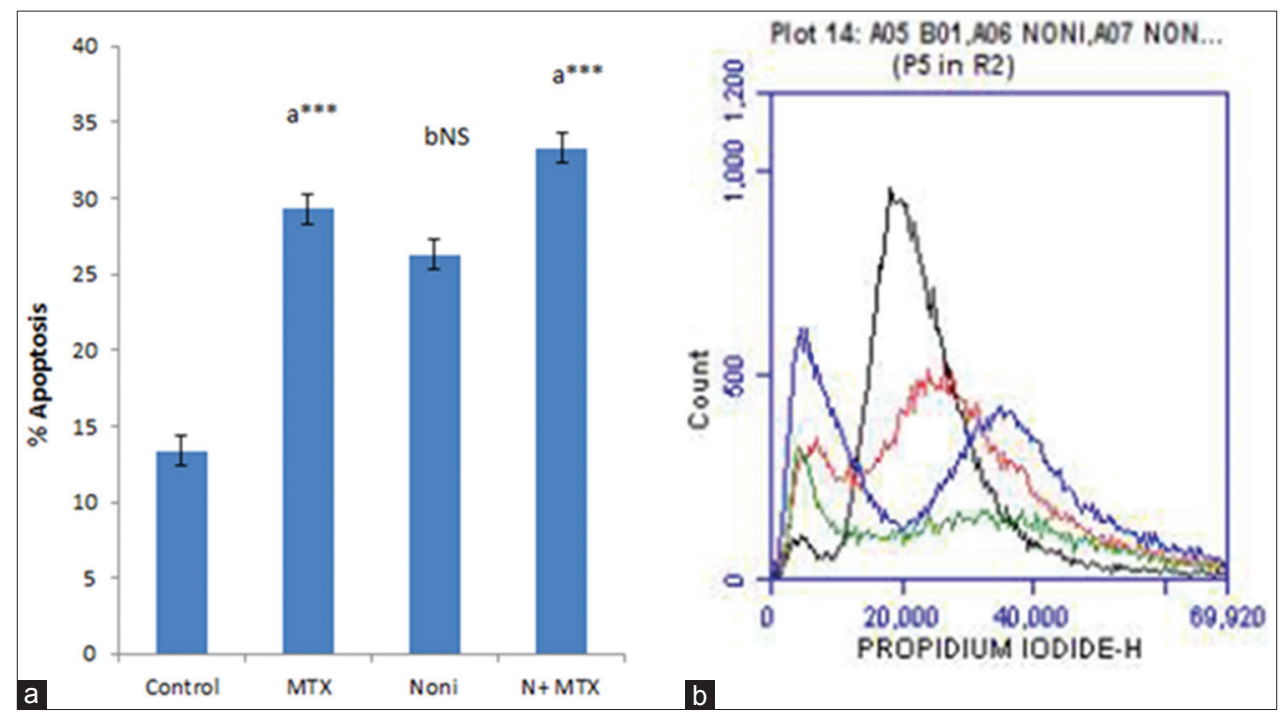

Fig. 9: Comparative graph of the percentage of apoptotic cells. (a) Results of flow cytometry analysis showing percentage apoptosis of HeLa cells in control and after $4.54 \mu \mathrm{g} / \mathrm{ml}$ of methotrexate (MTX), $8 \mathrm{mg} / \mathrm{ml} \mathrm{of} \mathrm{Noni,} \mathrm{and} \mathrm{combination} \mathrm{of} 8 \mathrm{mg} / \mathrm{ml} \mathrm{of} \mathrm{Noni}+4.54 \mu \mathrm{g} / \mathrm{ml} \mathrm{of}$ MTX treatment. (b) Plot of comparative percentage of apoptotic cell in control, $4.54 \mu \mathrm{g} / \mathrm{ml} \mathrm{of} \mathrm{MTX,} 8 \mathrm{mg} / \mathrm{ml}$ of Noni, and combination of $8 \mathrm{mg} / \mathrm{ml}$ of Noni $+4.54 \mu \mathrm{g} / \mathrm{ml}$ of MTX treated in HeLa cells by flow cytometry. Comparisons are expressed as "a" Groups I, II, III, and IV "b" Groups II and III, Statistical significance represented as: ${ }^{* *} p<0.01,{ }^{* * *} p<0.001$, NS: Non-significant

which regulates cell division and cell death leading to cytotoxicity that can maintain suitable cell number. Noni has been identified for its antiproliferative potential against tumor cells. In accordance, if plant extracts and their constituents have an ability to inhibit cancer cells without disturbing normal cells, they can have an immense potential in the treatment of cancer $[24,25]$. The synergistic combinations of Noni with existing anticancer drugs can enhance efficacy, reduce side effects, boost immune modulation, as well as abrogate drug resistance.

\section{CONCLUSION}

The results of this study show that Noni extract was able to induce growth inhibition, apoptosis, and cell cycle arrest alone and in 
combination with MTX. The combined use of Noni and lower MTX dose could potentially reduce the side effects/toxicity of the drug while not compromising on its therapeutic potential.

Noni as a chemoadjuvent can be one of the effective methods in reducing MTX dose administered to cancer patients during chemotherapy, thereby reducing toxicity to normal cells as well as side effects caused by chemotherapeutic drugs during the course of treatment.

\section{ACKNOWLEDGMENT}

We extend our deep sense of gratitude to Dr. Vainav Patel and Mr. Amit Singh from NIRRH and Dr. Akshita and Ms. Rekha Gour, ATREC, for providing timely help during flow cytometry study.

\section{AUTHORS' CONTRIBUTION}

Corresponding author, Dr. Thankamani Marar designed the experimental work, reviewed the manuscript, and also put a lot of efforts to improve the quality of the manuscript. Dr Bhakti A Mhatre carried out all laboratory work, data collections, and writing the manuscript.

\section{CONFLICTS OF INTEREST}

We wish to confirm that there are no known conflicts of interest associated with this publication and there has been no financial support for this work that could have influenced its outcome.

\section{REFERENCES}

1. Ruhomally Z, Somanah J, Bahorun T, Neergheen-Bhujun VS. Morinda citrifolia L. Fruit extracts modulates $\mathrm{H} 2 \mathrm{O} 2$-induced oxidative stressinhumanliposarcomaSW872 cells.JTraditComplementMed2016; 6:299-304

2. Gupta RK, Banerjee A, Pathak S, Sharma C, Singh N. Induction of mitochondrial-mediated apoptosis by Morinda citrifolia (Noni) in human cervical cancer cells. Asian Pac J Cancer Prev 2013;14:237-42.

3. Sawada K, Noda K, Nakajima H, Shimbara N, Furuichi Y, Sugimoto M. Differential cytotoxicity of anticancer agents in pre- and post-immortal lymphoblastoid cell lines. Biol Pharm Bull 2005;28:1202-7.

4. Wang MY, Nowicki D, Anderson G, Jensen J, West B. Liver protective effects of Morinda citrifolia (Noni). Plant Foods Hum Nutr 2008;63: 59-63.

5. Kumar DJ, Santhi RJ. Antioxidant and cytotoxic effects of hexane extract of Morinda pubescens leaves in human liver cancer cell line. Asian Pac J Trop Med 2012;5:362-6.

6. Mosmann T. Rapid colorimetric assay for cellular growth and survival: Application to proliferation and cytotoxicity assays. J Immunol Methods 1983;65:55-63.

7. Gong J, Traganos F, Darzynkiewicz Z. A selective procedure for DNA extraction from apoptotic cells applicable for gel electrophoresis and flow cytometry. Anal Biochem 1994;218:314-9.

8. Buch K, Peters T, Nawroth T, Sänger M, Schmidberger H, Langguth P. Determination of cell survival after irradiation via clonogenic assay versus multiple MTT assay - a comparative study. Radiat Oncol 2012;7:1.
9. Riccardi C, Nicoletti I. Analysis of apoptosis by propidium iodide staining and flow cytometry. Nat Protoc 2006;1:1458-61.

10. Balakrishnan SK, Bhat KI. Apoptosis and flow cytometric studies of Bauhinia variegate bark extract. Asian J Pharm Clin Res 2014;7:45-7. Available from: https://www.innovareacademics.in/journals/index.php/ ajpcr/article/view/793.

11. Da'i MA, Suhendi E, Meiyanto UJ, Kawaichi M. Apoptosis induction effect of curcumin and its analogs PENTAGAMAVUNON-0 and PENTAGAMAVUNON-1 on cancer cell lines. Asian J Pharm Clin Res 2017;10:373-6.

12. Kumar AG, Nandagopal S, Illanjiam S, Suganthi K, Dhanalakshmi DP, Joshua DE. Anti-proliferative activity and immunomodulator effects of Andrographis paniculata (Burm.f.) Wall. ex Nees against cancerous cell line. Pharmacia Lett 2016;8:17-22.

13. Saraswathi U, Revatni S, Jayanthi V. In vitro evaluation of antihepatocarcinogenic activity of an herbal formulation (Chathurmuka chooranam) against HEP G 2 cells. Int J Pharm Pharm Sci 2014;6:254-6.

14. Chaudhary S, Chandrashekar KS, Pai KS, Setty MM, Devkar RA, Reddy ND, et al. Evaluation of antioxidant and anticancer activity of extract and fractions of Nardostachys jatamansi DC in breast carcinoma. BMC Complement Altern Med 2015;15:50

15. Singh H, Banerjee S, Saumen K, Chatterjee TK. Evaluation of anticancer activity of Andaman freeze dried powdered Morinda citrifolia L. fruit against Ehrlich Ascites Carcinoma (EAC) cell induced liquid and solid tumor in Swiss albino mice. JPR BioMedRx 2013;1:567-73.

16. Banu N, Pavitra S. Anticarcinogenic effect of from Morinda citrifolia L. on HEPG2 cells. Int J Pharm Bio Sci 2015;6:145-55.

17. Mir H, Riaz M, Haseebur RN, Bilal R. Inhibition of wound closure and decreased colony formation by Clerodendrum infortunatum L. in lung cancer cell line. Int J Curr Res Biosci Plant Biol 2015;2:66-73.

18. Franken NA, Rodermond HM, Stap J, Haveman J, van Bree C. Clonogenic assay of cells in vitro. Nat Protoc 2006;1:2315-9.

19. Latifah SY, Faujan HA, Sze LP, Raha AR, Hisyam AH, Li OC. Curcumin from turmeric (Curcuma longa) induced apoptosis in human mammary carcinoma cells (MDA-MB-23). Malays J Med Health Sci 2006; 2:71-7.

20. Srinivasahan V, Durairaj B. Antioxidant and free radical scavenging effect of Morinda citrifolia fruit extract. Int J Pharm Pharm Sci 2014; 6:55-9.

21. Xie L, Zhao T, Cai J, Su Y, Wang Z, Dong W. Methotrexate induces DNA damage and inhibits homologous recombination repair in choriocarcinoma cells. Onco Targets Ther 2016;9:7115-22.

22. Aziz MY, Abu N, Yeap SK, Ho WY, Omar AR, Ismail NH, et al. Combinatorial cytotoxic effects of damnacanthal and doxorubicin against human breast cancer MCF-7 cells in vitro. Molecules 2016;21. pii: E1228

23. Alitheen NB, Aziz YA, Abu N, Yeap SK, Ho WY, Omar AR, et al. Combinatorial cytotoxic effects of damnacanthal and doxorubicin against human breast cancer MCF-7 Cells in vitro. Molecules 2016;21:1228-30.

24. Sharma K, Pachauri SD, Khandelwal K, Ahmad H, Arya A, Biala P, et al. Anticancer effects of extracts from the fruit of Morinda citrifolia (Noni) in breast cancer cell lines. Drug Res (Stuttg) 2016;66:141-7.

25. Kma L. Roles of plant extracts and constituents in cervical cancer therapy. Asian Pac J Cancer Prev 2013;14:3429-36. 